\title{
Indexical and Sequential Properties of Criticisms in Initial Interactions: Implications for Examining (Im) Politeness across Cultures
}

\author{
Michael Haugh ${ }^{1^{*}}$ and Wei-Lin Melody Chang ${ }^{1}$ \\ ${ }^{1}$ The University of Queensland, School of Languages and Cultures, \\ Gordon Greenwood Building, Union Road, The University of Queensland, \\ St Lucia, QLD 4072, Australia
}

\begin{abstract}
*Corresponding author:
michael.haugh@uq.edu.au
\end{abstract}

\begin{abstract}
Cross-cultural studies of (im)politeness have tended to focus on identifying differences in linguistic behaviour by which speech acts are delivered, which are then explained as motivated by underlying cultural differences. In this paper, we argue that this approach unnecessarily backgrounds emic or cultural members' understandings of (im)politeness. Through a comparative analysis of criticisms in initial interactions amongst Taiwanese speakers of Mandarin Chinese and amongst Australian speakers of English, we draw attention to the way in which similarities in the locally situated ways in which criticisms are delivered and responded to (i.e. their sequential properties) can mask differences in the culturally relevant meanings of criticisms (i.e. their indexical properties) in the respective languages. We conclude that cross-cultural studies of (im)politeness should not only focus on differences in the forms or strategies by which speech acts are accomplished, but remain alert to the possibility that what is ostensibly the same speech act, may in fact be interpreted in different ways by members of different cultural groups.
\end{abstract}

Keywords: (im)politeness, speech act, criticism, initial interaction, (Australian) English, (Mandarin) Chinese, cross-cultural pragmatics

\section{For citation:}

Haugh, Michael and Chang, Wei-Lin Melody (2019). Indexical and sequential properties of criticisms in initial interactions: Implications for examining (im) politeness across cultures. Russian Journal of Linguistics, 23 (4), 904 -929. doi: 10.22363/2312-9182-2019-23-4-904-929. 


\title{
Индексальные и последовательные свойства кри- тических замечаний в начале коммуникации: под- ходы к изучению (не)вежливости в кросс- культурном аспекте
}

\author{
Майкл Хо и Вей-Лин Мелоди Чанг \\ Университет Квинсленда, Австралия \\ Gordon Greenwood Building, Union Road, St Lucia, QLD 4072, Australia
}

\begin{abstract}
Аннотация
Кросс-культурные исследования вежливости и невежливости обычно нацелены на выявление различий в вербальном поведении, проявляющихся в реализации отдельных речевых актов, которые затем объясняются основными культурными различиями. В этой статье показано, что данный подход излишне опирается на эмический взгляд на (не)вежливость, т.е на ее понимание носителями данной культуры. Посредством сравнительного анализа критики в начальной фазе общения тайваньских носителей китайского языка и австралийских носителей английского языка мы обращаем внимание на то, как сходства в способах выражения критики и ответов на нее (то есть их последовательные свойства) могут скрывать различия в релевантных для культуры значениях критики (то есть различия их индексальных свойств) в соответствующих языках. Мы пришли к выводу, что межкультурные исследования (не)вежливости должны не только выявлять различия в формах и стратегиях, с помощью которых реализуются речевые акты, но и учитывать то, что якобы одни и те же речевые акты на самом деле могут быть по-разному истолкованы членами различных культурных групп.
\end{abstract}

Ключевые слова: (не)вежливость, речевой акт, критика, начальная фаза взаимодействия, австралийский английский, китайский (мандарин), кросс-культурная прагматика

\section{Для цитирования:}

Haugh, Michael and Chang, Wei-Lin Melody (2019). Indexical and sequential properties of criticisms in initial interactions: Implications for examining (im) politeness across cultures. Russian Journal of Linguistics, 23 (4), 904 - 929. doi: 10.22363/2312-9182-2019-23-4-904-929.

\section{Introduction}

Studies of (im)politeness across languages and cultures have generally focused on identifying differences in (linguistic) behaviour that are then explained as cultural differences, with much of this work in cross-cultural pragmatics focusing on requests, apologies, compliments and compliment responses (Sifianou \& Garcés-Conejos Blitvich 2017: 584). Brown and Levinson's $(1978,1987)$ politeness theory has long been a popular vehicle for these kinds of cross-cultural (im)politeness studies, in large part because that is what Brown and Levinson's theory was designed to do. While the discursive turn in (im)politeness research has subsequently challenged the validity of Brown and Levinson's approach (Eelen 2011; Mills 2003), such critical work has not provided a clear alternative way forward for studying (im)politeness across languages and cultures (Grainger 2013; Sifianou \& Garcés-Conejos Blitvich 2017). This has led to a return to a neo-Brown and Levinsonian stance, in which the same theoretical tools (positive and negative face, face-threatening acts and so on) are deployed with discourse data, as opposed to the utterance-based analyses found in Brown and Levinson's original 
work $^{1}$. This has, in turn, reinforced the view that cross-cultural studies of (im)politeness are about identifying differences in (linguistic) behaviour, which are then explained as motivated by underlying cultural differences.

One problem with this approach, however, is that it under-estimates the extent to which the same (linguistic) behaviour can have different meanings for members across languages and cultures. This point was already noted in passing by House and Kasper (1981) in their concluding remarks of a comparative study of "complaints" in English and German.

From an etic standpoint, then, the behaviour of the German speakers may well be considered impolite by reference to an English norm; however, from an emic standpoint, which is the one we would prefer here, one would simply claim that the differential behaviour displayed by the German and English speakers may be a reflection of the fact that the two cultural systems are organized differently, and that, e.g., a level 6 complaint in the German culture is not necessarily comparable to a level 6 complaint in the English culture, because the value of each is derived from the value it has relative to the remaining levels, and their frequency and modality of use in the particular cultural system (House and Kasper 1981: 184).

It follows from House and Kasper's comparative analysis that although British and German speakers of English may readily understand a "complaint" is being made through a particular form, they may not be aware that the (im)politeness value of that "complaint" is likely to be different depending on the cultural background of the speaker. The point made here by House and Kasper (1981) arguably has important implications for both cross-cultural and intercultural studies of (im)politeness. In the case of crosscultural studies of (im)politeness, we have the problem of ensuring we are actually comparing like with like. House and Kasper (1981) claim that while the same form may deliver the same speech act across two languages, its so-called "(im)politeness value" may differ. In other words, the indexical value of analogous syntactic forms is different across English and German. Comparing the same forms therefore does not amount to comparing the same thing. In the case of studies of (im)politeness in intercultural settings, the potential for "hidden misunderstandings" (Carbaugh 2005) is clear, given the same form may have different indexical values unbeknownst to those participants.

In recent years researchers have shifted from the emic-etic distinction to making a distinction between first-order participant and second-order analyst understandings of (im)politeness (Watts, Ide \& Ehlich 1992; Eelen 2001). In much of this work, participant understandings are treated as essentially synonymous with emic (or cultural members') understandings, and analyst (or scientific) understandings are treated as synonymous with etic (or cultural non-members') understandings. In short, the emicetic distinction has been more or less reconstrued as a distinction between first-order participant and second-order analyst understandings.

1 A move that was advocated by Brown and Levinson themselves in their introduction to the 1987 reissue of the original 1978 publication. 
An underlying theoretical question this raises for (im)politeness research is whether the emic-etic and participant-analyst distinctions actually encapsulate the same thing. There has been some debate about this by (im)politeness researchers (Haugh 2012; Kádár \& Haugh 2013; Spencer-Oatey \& Kádár 2016), in part, because there are different extant definitions of the emic-etic distinction (Headland, Pike \& Harris 1990). The emic-etic distinction can be made with reference to participants, systems or both. When the emic-etic distinction is applied to participants (i.e. cultural members/insiders versus non-members/outsiders), it is invoked as grounds for interpretation by analysts. When the emic-etic distinction is applied to cultural systems (i.e. culture-internal versus culture-comparative orientation), it is invoked as grounds for theorisation by scientific observers. In other words, the emic-etic distinction can be conceptualised in two distinct ways with respect to participants and analysts.

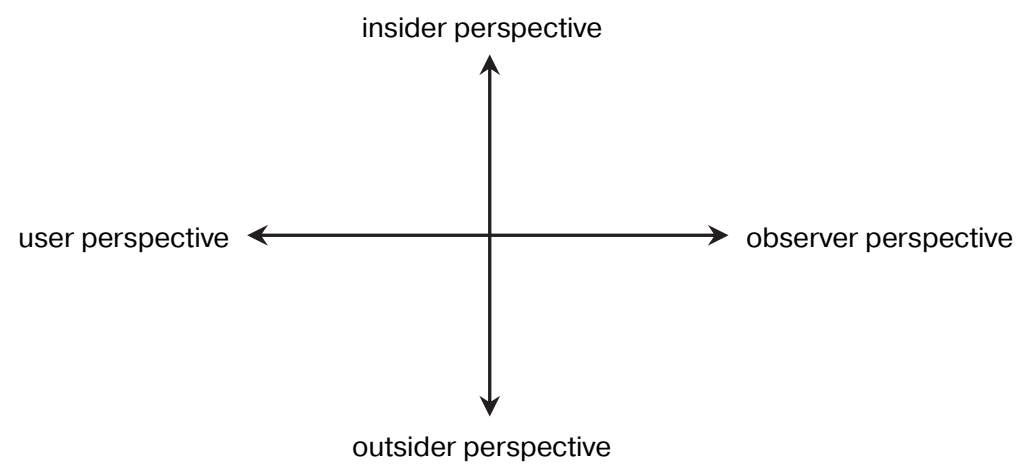

Figure 1. Theorising perspectives on talk and conduct

These perspectives are, of course, necessarily interlinked in that analysis presupposes theorisation of some sort or another (even if that theorisation is only tacit), while theorisation presupposes analysis of some sort or another (even if that analysis is only introspective in nature). Different researchers place varying emphasis on these different possible perspectives and how they might be formally interlinked.

In this paper, the overall aim is to examine the role of emic or cultural members' understandings in studies of (im)politeness across languages and cultures. We attempt to do this through the lens of a speech act that has not received much attention to date in (im)politeness research, namely, criticisms. We examine criticisms, specifically other-criticisms, in initial interactions in which participants are getting acquainted. The advantage of this type of data is that in such settings the relational history of the participants is transparent to the analyst. The culturally relevant meanings of criticisms (i.e. their indexical properties), and the locally situated ways which they are delivered and responded to (i.e. their sequential properties), are thus equally accessible to both participants and analysts.

We begin, in the following section, by briefly discussing prior research on criticisms, before going on, in section 3, to introduce the dataset in question and outline our methodological approach. We next report, in section 4, on our comparative analysis of criticisms in initial interactions amongst Taiwanese speakers of Mandarin Chinese 
versus criticisms in initial interactions amongst Australian speakers of English. Building on this comparative analysis we argue, in section 5, that while these criticisms may have similar sequential properties, they nevertheless have distinct indexical properties. In short, we claim that while the criticisms are delivered and responded to in similar ways by the participants in both languages, from an emic (i.e. cultural members') perspective the evaluative and relational import of these criticisms is not the same for speakers of these two languages. We conclude by briefly discussing the implications of our study for cross-cultural (im)politeness research.

\section{Prior research on criticisms}

The act of criticism involves pointing out some kind of fault (i.e. weakness, failing, misdemeanour or mistake) for which a party is presumed to be responsible, and expressing disapproval of that fault (Merriam-Webster Dictionary Online 2019; Oxford English Dictionary Online 2019). In short, "to negatively evaluate a person for some act or quality for which that person is deemed responsible" (Pillet-Shore 2016: 54). In some cases, the speaker also implies that the criticised target should do something to remedy or address that fault (Nguyen 2008: 45; Pillet-Shore 2015: 375).

Researchers have often studied criticisms together with complaints, accusations, reproaches, and the like without differentiating between them (e.g. D'Amico-Reisner 1983; House and Kasper 1981; Malle, Gugliemo \& Monroe 2014; Morris 1988). However, conflating these acts is arguably problematic. From a speech act theoretic perspective, while all these different actions constitute assertions of some kind of fault - or offence, transgression or wrongdoing etc. - on the part of the referent, they can nevertheless be distinguished on semantic grounds (Vanderveken 1990; Wierzbicka 1987). From an interactional perspective, participants in interaction can be shown to display investment in discerning between these acts as well. Pillet-Shore (2016), for instance, points out that one can criticise without complaining, and draws attention to systematic ways in which participants may orient to this distinction in parent-teacher interviews.

In (im)politeness research, criticisms have generally been treated as a facethreatening act (Brown \& Levinson 1987: 66), which can thus be used as an impoliteness strategy (Bousfield 2008; Culpeper 2011, 2015) ${ }^{2}$. For that reason, criticisms are claimed to be prototypically delivered via off-record strategies, including through hints, presuppositions, understatements, tautologies, contradictions, irony, rhetorical questions and over-generalisations (Brown \& Levinson 1987: 213-226). They also note, in passing, that criticisms can be implied through soliciting accounts or reasons for some state of affairs for which the addressee is held responsible (pp. 128-129; cf. Bolden \& Robinson 2011). The focus in (im)politeness research has largely been on criticisms that are delivered to prompt some kind of action or change on the part of the target. Brown and Levinson (1987) claim, for instance, that "the construction of hints for other FTAs not requiring $\mathrm{H}$ [earer] to perform some act — for indirect criticisms, for instance — involves complex processes beyond the scope of this paper (and, indeed, beyond our present understanding)" (p. 215).

${ }^{2}$ Criticisms can, of course, be delivered within a non-serious or joking key or frame, in which case they are regarded as a means of showing solidarity or intimacy (Brown \& Levinson 1987; Leech 1983). 
A survey of empirical work on criticisms to date suggests that little has changed in that respect. While there have been a number of studies of criticisms that are designed to suggest or even require that the fault in question be redressed, we still know very little about criticisms where the aim is to insult or wound the target (Tayebi 2018). Empirical studies have focused for the most part on examining criticisms in institutional contexts, including in appraisal meetings in which supervisors are evaluating work performance (Asmuß 2008; Copland 2011; Schuer 2014; Tracy \& Eisenberg 1990/91), in feedback sessions where academic work is being evaluated (Li \& Seale 2007; Nguyen 2008), or in parent-teacher interviews in which students' work is being reported upon (Pillet-Shore 2015, 2016). In such contexts, criticisms are licensed by the roles of participants in those settings. However, while criticisms may be licensed in such settings, they are nevertheless invariably treated as sensitive, dispreferred and face-threatening social actions. Participants have been shown to orient, for instance, to the fact that criticisms can cause hurt feelings (Copland 2011), convey expectations that the target will do something to remedy the fault (Pillet-Shore 2015), pass (unwelcome) moral judgment on others (Asmuß 2008), or display claims to have expertise or knowledge about the target that may be resisted by the latter (Pomerantz 1984).

Less frequently, criticisms have been examined in interpersonal, everyday contexts (e.g. Lang 2018; Tayebi 2018; Tracy, Van Dusen \& Robinson 1987), although such studies have relied, for the most part, on fictional data, field notes or diary reports, with the exception of early work by Pomerantz (1984) on assessments in naturally occurring conversations. The latter notes that in everyday conversation criticisms are typically delivered with a dispreferred action or turn shape (if at all). To the best of our knowledge, then, there are very few studies that have examined how criticisms arise and how they are responded to in everyday, interpersonal interactions, and even fewer that attempt to compare criticisms across languages and cultures, despite Brown and Levinson (1987) acknowledging that the extent to which criticisms are considered face-threatening can vary across cultures.

In the following sections, we attempt to begin to redress that gap through reporting on a case study in which we compared criticisms arising in initial interactions amongst Taiwanese speakers of Chinese with those arising in initial interactions amongst Australian speakers of English.

\section{Data and method}

Our collection of criticisms was assembled drawing from two different corpora. The first is the Australians Getting Acquainted (AGA) corpus, a collection of eighteen audio-recordings and associated transcripts of initial interactions amongst Australian speakers of English (approximately five hours in total) (Haugh 2011). The second is a subset of the Mandarin Conversation Dialogue Corpus (MCDC), a collection of ten audio-recordings and associated transcripts of initial interactions amongst Taiwanese speakers of Mandarin Chinese (approximately eight hours in total) (Tseng 2004, 2008). Ten conversations were selected from AGA in order to match the gender and age pairings in the ten conversations taken from MCDC. The 10 interactions from each corpora consisted of the same sets of gender pairings (4 same-gender; 6 different gender pairings), 
and the same sets of age pairings (7 similar age; 3 different age pairings). Both corpora employed the same protocol implemented by Svennevig (1999): it was explained to voluntary participants that they were being recorded for the purposes of studying communication, but no specific topics to talk about were given to them.

Our analysis began by jointly identifying putative instances of criticism in the comparative dataset in cases where we agreed that a negative evaluation of the other interlocutor was readily inferable. This was accomplished through listening to the entire recording of every interaction. For the purposes of this exercise we define a criticism as an instance in which a speaker negatively evaluates the conduct or character of their co-present interlocutor, that is, indicates disapproval of the conduct or character of the addressed recipient (Pillet-Shore 2016: 54) ${ }^{3}$.

In excerpt (1), for instance, Natalie assesses Gary's enunciation as unclear in lines 201-202 (the turn in question is marked with an arrow in the transcription below).

(1) AGA09: 7:10

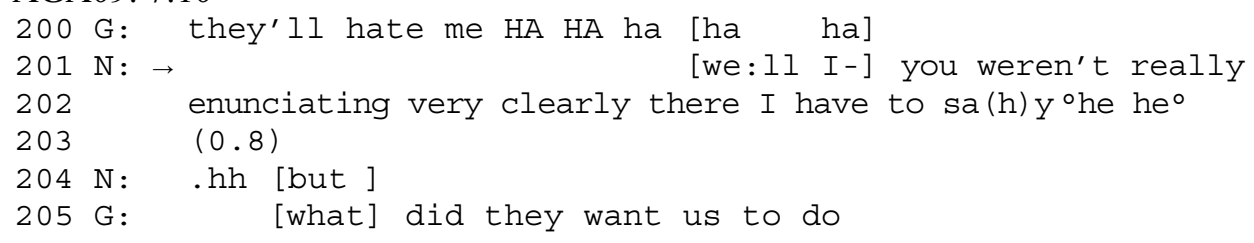

Assessments are defined as "utterances that offer an evaluation of a referent with a clear valence (e.g. as good, bad, outrageous, tragic, or funny)" (Stivers \& Rossano 2010: 9; cf. Couper-Kuhlen \& Selting 2018: 283). In other words, assessments are positive or negative evaluations of a person, third party, external object or situation arising through current or past participation in joint activity (Goodwin \& Goodwin 1992; Pomerantz 1984). Assessments can implement a range of different actions depending on the target and valence of the assessment, including compliments, selfpraise, self-deprecations and criticisms or reproaches (Couper-Kuhlen \& Selting 2018; Edwards \& Potter 2017). In the above case, the assessment implements a criticism as Natalie is negatively evaluating Gary's current enunciation, and shows disapproval (due to the trouble this will cause for those who will be later transcribing their conversation $)^{4}$. She orients to the sensitivity of this criticism through interpolated aspiration and laughter at the end of the turn in question (Shaw, Hepburn \& Potter 2013).

After identifying potential instances of criticism, we then closely examined the sequential environments within which these criticisms arose through reviewing the recordings, and closely transcribing the instances in question using conventions from conversation analysis (Jefferson 2004). In the case above, the (serious) other-criticism

${ }^{3}$ Criticisms can be other-directed or self-directed. As the term self-deprecation is commonly used in the literature to refer to self-criticisms, we use the term criticism here in the way it is normally used by researchers to refer more specifically to instances of other-criticism, unless it is important for our analysis to draw attention to that distinction.

${ }^{4}$ Just prior to this excerpt they have been talking about how their conversation will be boring to listen to for the transcribers (data not shown). 
in question arises in response to a (joking) self-criticism by the prior speaker. However, we found through detailed sequential analysis of our set of candidate examples that criticisms in initial interactions are more typically implemented via barbs or teases, rather than through explicit negative assessments.

A barb is a criticism in which a negative evaluation of other is implied, rather being explicitly delivered through a clearly valenced adjective (e.g. wonderful, good, awful, boring, unclear). In other words, the criticism is made available through inference to the recipient rather than through what is explicitly said. Prior to excerpt (2), Natalie has been prompting Gary to ask her some questions. He responds by claiming he has no questions to ask her.

(2) AGA09: 8:00

$\begin{array}{ll}346 \mathrm{G}: & \mathrm{U}: \mathrm{M} \text { I haven't got any questions to } \uparrow \text { ask you } \\ 347 & \text { actually. } \\ 348 & (1.1) \\ 349 \mathrm{~N}: \rightarrow & \text { } \text { you must be fun at parties. Hhh } \\ 350 \mathrm{G}: \quad & \text { \#don't like parties\# }\end{array}$

Natalie responds, in turn, by assessing Gary as someone who must be "fun" at parties (line 349). In this case, however, it is clear that she is being sarcastic and implying the opposite, namely, that he would not be fun at parties. In so doing she implies that he is a poor conversationalist, and possibly a boring person. The implied criticism here thus consists of a barb about his character. Notably, Gary responds to this barb by claiming he does not like parties (line 350), thereby undermining the relevance of Natalie's barb for him (cf. Haugh 2011: 178-179) ${ }^{5}$.

A tease is an (ostensibly) playful or jocular mocking jibe or taunt directed at another party. It is thus another way of criticising others, albeit one in which the teaser can disclaim responsibility for this criticism through claims to have been "just kidding", "only joking", "just teasing" and so on (Haugh \& Pillet-Shore 2018). In excerpt (3), Gary is talking with Emma about how traditional Chinese culture has been pushed aside in modern China

(3) AGA03: 7:14

\begin{tabular}{|c|c|c|}
\hline $\begin{array}{l}176 \\
177\end{array}$ & E: & $\begin{array}{l}\text { so: um }(0.5)<y e a: h>(.) \text { any of the old }(0.9) \\
\text { any of the old ways any of the intuitive \#stuff\# }\end{array}$ \\
\hline 78 & & (0.3) they've pretty much got rid of. $(0.5)$ and \\
\hline 179 & & looked at all the scientific si :de of it. (.) \\
\hline 180 & & which I think is a real trage $\overline{d y}$. \\
\hline-81 & & $(2.8)$ \\
\hline 182 & G: & (oh) ${ }^{\circ}$ just move $\circ: \mathrm{n}^{\circ}$ (.) you know ${ }^{\circ} \mathrm{hh}$ hh hh hho \\
\hline 183 & $E: \rightarrow$ & 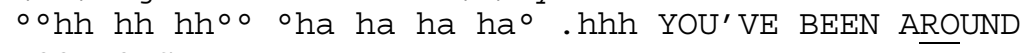 \\
\hline 184 & & TOO LONG= \\
\hline 185 & G : & $=\mathrm{AH}$ HA HA ha ha ha ha ha ha \\
\hline 86 & $\mathrm{E}:$ & hah .hh $\mathrm{HAH}$.hhh you've been around $t$ - for too \\
\hline 87 & & many $1 i$ :feti:mes.= \\
\hline 88 & G & $=a h$ ha ha ha $(0.3)$ \\
\hline
\end{tabular}

Gary describes this as a real tragedy (line 180). However, after a gap in which Emma does not affiliate with his assessment (line 181), he subsequently suggests they

5 This is subsequently developed by Gary into an account (see example 10). 
“just move on" (line 182). This occasions a tease in lines 183-184 by Emma that Gary has "been around too long" (i.e. that he's overly jaded or cynical), which prompts shared laughter (lines 185-186), a repeat of the tease by Emma (lines 186-187), and subsequent laughing agreement from Gary (line 188). In this case, the criticism that Gary is overly jaded is treated, ostensibly at least, as non-serious by both participants.

\section{Comparative analysis of criticisms in initial interactions}

A number of key findings emerged from our comparative case study of criticisms in initial interactions amongst Australian speakers of English and Taiwanese speakers of Mandarin Chinese. First, despite being characterised as an inherently face-threatening act (Brown \& Levinson 1987), criticisms were nevertheless found to arise in initial interactions amongst both Australian and Taiwanese participants. However, only instances of barbs were found to occur across both datasets. It was also evident that criticisms are treated as dispreferred actions in initial interactions by both Australian and Taiwanese participants. Second, there were two formats through which criticisms are commonly delivered: assessments and account solicitations. Third, criticisms can target either the character or the conduct of the other party. We now move to discuss, in turn, each of these findings in more detail.

\subsection{Criticisms and responses to criticisms in initial interactions}

Criticisms in initial interactions were delivered off-record through barbs or teases rather than through explicit negative assessments. This is not surprising given earlier claims that explicit criticisms threaten the positive face of hearers (Brown \& Levinson 1987: 66) or are treated as dispreferred (Pomerantz 1984: 78). These findings are summarised in Table 1. The number outside of the bracket refers to the frequency of occurrence in each dataset, while the percentage inside the brackets refers to the proportion of interactions in which they occurred.

Table 1

Criticisms in Australian and Taiwanese initial interactions

\begin{tabular}{|l|c|c|}
\hline & Australian (AGA) & Taiwanese (MCDC) \\
\hline Explicit negative assessment & $2(10 \%)$ & 0 \\
\hline Barb & $7(20 \%)$ & $6(30 \%)$ \\
\hline Tease & $12(70 \%)$ & 0 \\
\hline
\end{tabular}

While there only two instances of explicit negative assessments (see examples 1 and 10), barbs were found across both corpora: six barb sequences across three interactions were identified in the Taiwanese initial encounters, and seven barb sequences across two interactions were identified in the Australian dataset. While criticisms are relatively low frequency occurrences in initial interactions, they are nevertheless more frequent than one might expect, given that barbs were identified in five out of the twenty initial interactions we examined. A notable difference, however, was that there were no instances of criticisms delivered via teases in the Taiwanese dataset, while twelve tease sequences were found across seven interactions in the Australian dataset. 
A recurrent pattern in responses to criticisms also emerged in the course of our analysis. We found that barbs invariably occasioned accounts from the target (Chang forthcoming), that is, overt explanations of the reasons, motives or causes of one's conduct or character (Heritage 1988). Teases, in contrast, recurrently occasioned laughter (Haugh \& Pillet-Shore 2018). The fact that accounts regularly follow barbs provides data-internal evidence that the participants were indeed orienting to the prior turn as implying criticism.

It appears, then, that criticisms in initial interactions are treated as dispreferred actions. The evidence for making this claim is two-fold. First, other-criticisms are delivered through implicated conclusions or implicated premises rather than being made through explicit negative assessments. Second, the targets of those barbs invariably respond with accounts that undermine the relevance or aptness of those criticisms, rather than with denials that directly disagree with them.

\subsection{Formats of criticisms in initial interaction}

A second finding was that criticisms are delivered through two key formats across both sets of initial interactions. The first vehicle involves assessments through which speakers implicate negative evaluations of the character or conduct of the other interlocutor.

We have already seen an example of this format in the Australian dataset (see example 2). The same format was also found to occur in the Taiwanese dataset. In the following example taken from MCDC, Wang and Chang have been talking about how the latter gets to work. Excerpt (4) begins with Wang asking Chang whether he knows if a particular famous village is near where the latter works.

(4) MCDC25:01:2:35

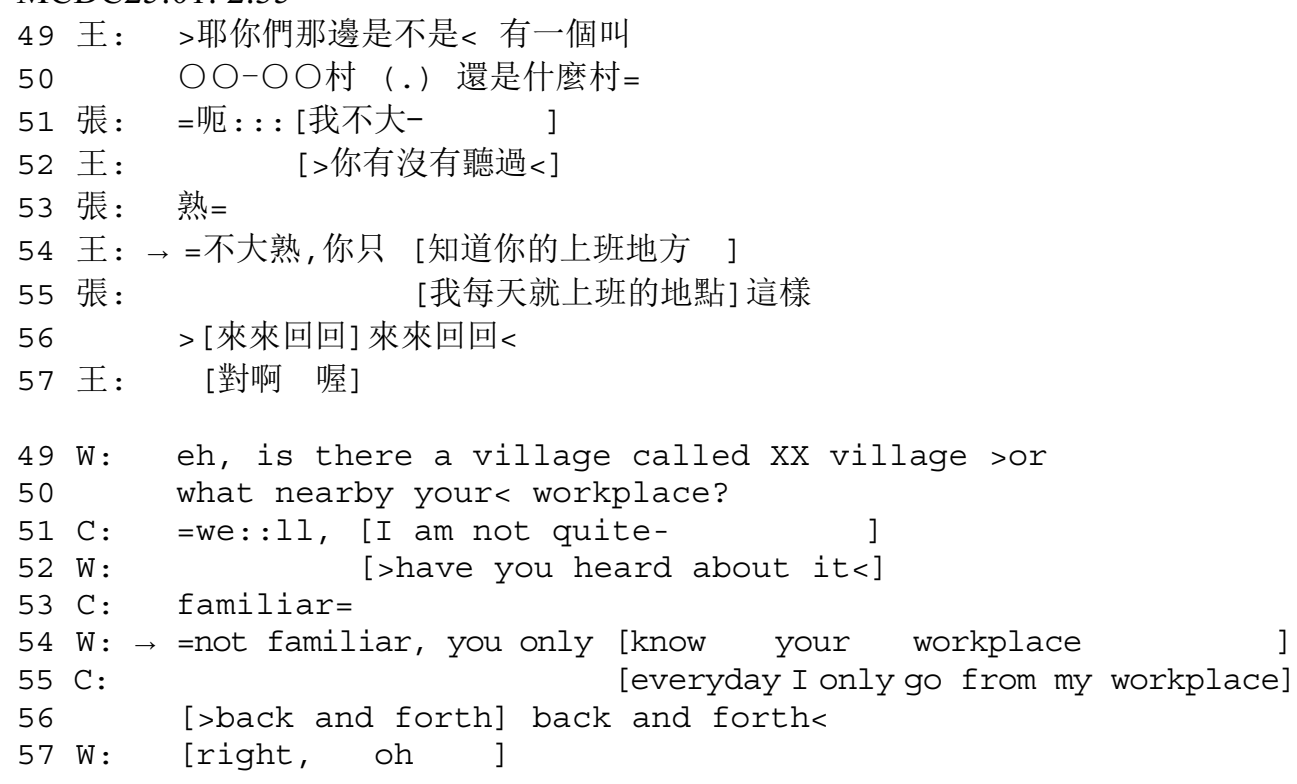

Chang responds that he is not familiar with it (lines 51, 53), while Wang follows up in overlap with an epistemic check about whether Chang has heard of that village 
(line 52). Wang then confirms through a partial repetition that Chang is not familiar with the village before going on to offer an assessment that Chang's knowledge is limited to his workplace (line 54). In assessing Chang as only knowing his workplace, Wang implies that Chang only thinks about his work and is unaware of interesting things outside of it. The latter amounts to a barb about his character: that he concentrates too much on his workplace, and consequently is a boring person. The negative evaluative import of this assessment is evident from Chang's subsequent account as to why he is not familiar with the village in question (lines 55-56). In short, by providing an account, Wang orients to the way in which he is being held accountable by Chang for not knowing about this famous village which is near the former's workplace.

The second format for delivering barbs involves questions designed to solicit accounts. Notably, although account solicitations can imply criticism (Robinson \& Bolden 2010), since these criticisms are delivered off-record, they are readily deniable by the speaker (Brown \& Levinson 1987: 128-129). We term these presumptive questions, as a common feature of these questions was that they presupposed a negative evaluation of some aspect of the character or conduct of the recipient.

Prior to excerpt (5), which is taken from AGA, Chris has asked Emma why she decided to take up acupuncture as a career. Emma has been explaining that it was because she was experiencing poor health and was exploring alternative approaches, including Chinese medicinal approaches.

(5) AGA02: 14:14

$558 \mathrm{E}$ : and I uh- I also tried acupuncture and Chinese herbs

559 and they didn't wo:rk $(0.6)$ but (0.3) um

$560 \quad(0.2)$

$561 \mathrm{C}: \rightarrow$ so even after not working you sor- thought

$562 \quad(0.2)$

$563 \mathrm{E}: \quad[\uparrow$ we: 11$]$

$564 \mathrm{C}: \rightarrow$ [gee I ] could pursue this as a career

$565 \mathrm{E}: \quad$ yeah $\uparrow \mathrm{n} \downarrow \mathrm{O} \uparrow \mathrm{i}$ iked the $\downarrow$ wa:y (.) when I went

566 to the acupuncturist I like that (.) she worked

567 and how (1.1) u:m (0.3) nice she was

After claiming accupuncture did not work for her (line 559), Chris goes on to solicit an account through a $s o$-prefaced question that returns to the question of why Emma took up acupuncture in the first place (lines 561, 564). In this case, the question is designed to draw attention to a seeming contradiction, the fact that Emma took up acupuncture as a career even though it did not actually work for her personally. Embedded in this question, then, is an implicated premise that he is critical of her reasoning with respect to her choice of career, and thus potentially of her capacity for logical reasoning. The negative evaluative import of this presumptive question is evident from Emma's well-prefaced (line 563), and subsequent yeah no-prefaced account (lines 565-567), which attends to the different inferences made available through Chris's question.

A barb about the character of the other participant is also delivered through a presumptive question in excerpt (6), taken from MCDC, between Yeh and Lee. Preceding this excerpt, Lee has sought an account from Yeh as to why he has not yet travelled overseas. He begins his account by saying that it costs a lot of money (relative to what he earns each month). 
(6) MCDC02:10: 0:54

28 葉: 一個月一年一個月一年你才多少薪水

29 李: 恩 [嗯嗯]

30 葉: [然後] 你扣掉平常那個 (.)

31 消費然後你還要存下來我以後少想對不對=

32 李: =恩=

33 葉: =那 - 想 - 所以說你會 - 會很珍惜每一 - 每 -

$34>$ 每一個<資源啊 (.) 你會-

35 李: $\rightarrow$ 你-你 - 你平常是很省的人嗎?

$36 \quad(0.2)$

37 葉: 㕪: : , 也許吧 (hhh)

38 李: 也許?=

39 葉: => 然後< 恩那-我-我-我-因為有 - 就像 -

40 (.) 因為我又不知道女孩子的想法

28 Y: think about how much you earn every month and every year.

$29 \mathrm{~L}: \mathrm{mm}$ [mm $\mathrm{mm}]$

$30 \mathrm{Y:} \quad[$ then ] you deduct your daily expenses (.)

31

and then you have to save up, right?=

$32 \mathrm{~L}: \quad=\mathrm{mm}=$

$33 \mathrm{Y}:=$ =then- want- so you cherish each- each-

34 >every< resource right? (.) you-

$35 \mathrm{~L}: \rightarrow$ you- you- you- are you the person who likes saving up?

$36 \quad(0.2)$

$37 \mathrm{Y}: \quad$ we: :ll, maybe (hhh)

$38 \mathrm{~L}:$ maybe?=

$39 \mathrm{Y}:=>$ then< I am like- I- I- I- because there is- just like-

40 (.) because I don't know what girls are thinking

Yeh goes on to make a generalised claim that everyone wants to be careful about what they spend (lines 30-34). However, rather than agreeing with this claim, Lee asks, in line 35, whether Yeh is a person who likes saving up and economising, as opposed to spending his money. Embedded within Lee's question, given it latches on to the account provided by Yeh, is the presupposition that he has not travelled because he prefers to save his money. In so doing, she implies that he is stingy. The negative evaluative import of this presumptive question is evident, in line 37, from Yeh's wellprefaced assent, and subsequent disfluently delivered account for his focus on saving rather than travelling, namely, he does not know what girls want (lines 39-40).

\subsection{Targets of criticism in initial interactions}

A third finding was that barbs may target either the character or the conduct of the co-present interlocutor. We have seen instances, in excerpts (2) and (4-6) above, of barbs targeting the character of the recipient. In the following two examples, taken from AGA and MCDC respectively, the barbs in question target the in situ conduct of the recipient.

Prior to excerpt (7), taken from AGA, Natalie has been talking for some time about the pressure of doing an honours degree. Notably, Gary has not initiated any topics by asking Natalie any questions up until this point in the conversation. 
(7) AGA09: 4:16

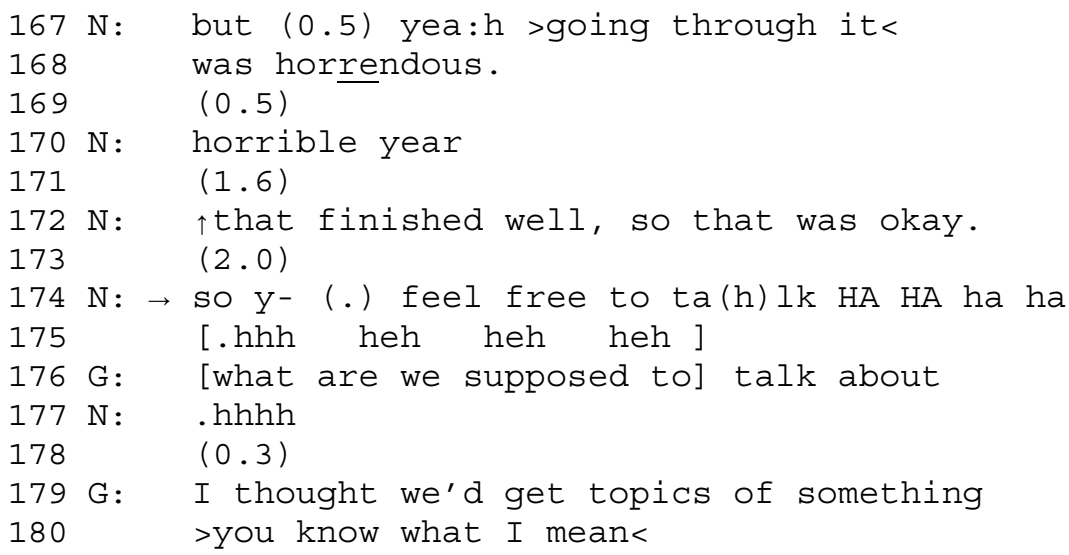

Typical of a storytelling sequence (Stivers 2008), Natalie is winding it up with assessments of the year as "horrendous" (lines 167-168). Following a beat with no affiliative response from Gary, Natalie redoes a sequence-closing implicative negative assessment of the year as "horrible" (line 170). Following a longer gap where there is no affiliative response from Gary, she next offers an alternative assessment, which modulates the valence to the more positive "finished well" (line 172). A long gap follows in which Gary does not affiliate with that assessment either (line 173). This series of lapses is indicative of topic withering (Haugh \& Musgrave 2019). Natalie suggests that it is now Gary's turn to say something (line 174). This metapragmatic comment not only points to the prior trouble they have just experienced in sustaining their conversation, but implies that Natalie is laying the blame for this topic withering on Gary, criticising him for not carrying his fair share of the conversational load by asking her some questions. Natalie orients to the evident sensitivity of this barb by modulating it through interpolated aspiration and turn-final laughter (Shaw, Hepburn \& Potter 2013). The negative evaluative import of Natalie's laughing suggestion is also evident from Gary's subsequent account as to why he is not talking more, namely, he had expected they would be given topics (lines 176, 179-180). This implies the fault lies with the researcher who arranged their initial encounter rather than Gary, thereby deflecting blame away from him.

A similar pattern emerges in the next excerpt taken from MCDC, in which Wu initiates a new sequence, following brief self-introductions, about what Zhang was doing prior to their meeting. An important point to note is that $\mathrm{Wu}$ had been left waiting by Zhang, who arrived late.

(8) MCDC09:01:0:15
06 巫：妳剛才是從哪裡來 >不然妳還-<
07 妳不是開車還要下高速公路
08 張: 哦我今天早上到板橋去=
09 巫: $={ }^{\circ} \uparrow$ 哦 ${ }^{\circ}=$
10 張: =到: 那個朋友那邊 $($.$) 找他喝咖啡=$
11 巫: $\rightarrow=$ o哇: (.) 這麼 [閒 $h h h \circ$ ]
12 張:
[那我本來] 想說很快就可以到這邊來的啊 


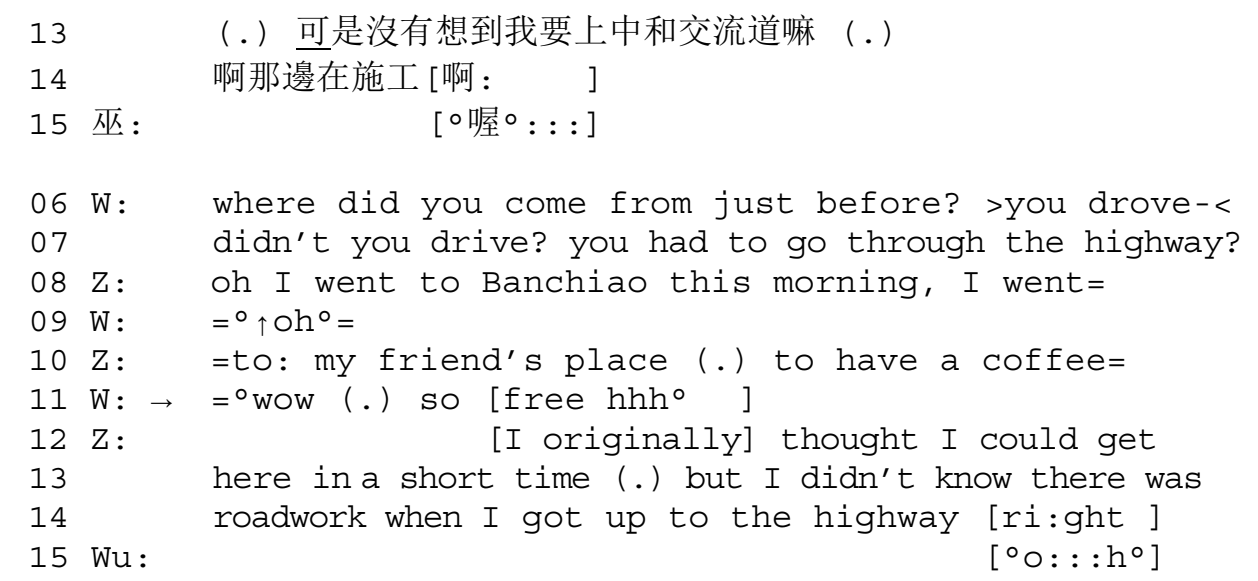

Rather than initiating the sequence with an open question (e.g. what have you been doing this morning?), however, $\mathrm{Wu}$ offers a candidate account that Zhang was late because of traffic (lines 6-7). Zhang responds that she went to her friend's place to have a coffee (lines 8,10$)$. Wu initially responds, in line 9 , with a softly delivered news receipt particle that displays surprise (Wilkinson \& Kitzinger 2006), before going on in line 10 to offer an assessment of Zhang as "so free" (in the sense of idle, i.e., not making good use of her time). Given that this is followed by an implicit account solicitation as to why she was late, Wu thus implies that Zhang did not have a good reason to be late, thereby criticising her conduct ${ }^{6}$. The negative evaluative import of this assessment is evident from Zhang's subsequent account in which she claims she was late due to roadworks (lines 12-14).

Overall, then, the sequential pattern across both languages appears to be remarkably similar. On a standard cross-cultural analysis this would suggest that there is no significant difference between these two sets of speakers. It would appear that criticisms are treated as equally dispreferred, and thus potentially impolite, by both (Australian) English and (Taiwanese) Mandarin Chinese speakers. In the following section, however, we suggest that reaching such a conclusion would be premature.

\section{Sequential and indexical properties of criticisms in initial interactions}

Criticisms are typically considered to be sensitive, dispreferred and face-threatening actions. In short, criticising the other persons seems, at first glance, to be an impolite thing to do in an initial interaction. This raises a puzzle as to why they occur so readily, especially given the emphasis typically placed on avoiding disagreement in such contexts (Haugh 2015a; Flint, Haugh \& Merrison 2019). One possibility is that criticisms can be a means of inviting intimacy, particularly if they are construed by participants as teasing or playful (Dayter \& Rüdiger 2018; Haugh \& Pillet-Shore 2018; Hambling-Jones \& Merrison 2012). However, our view is that in order to better understand what the

${ }^{6}$ It also potentially constitutes a criticism of her character, but through her subsequent account, Zhang orients to it specifically as a criticism of her just prior conduct (i.e. being late). 
apparently serious criticisms we have examined here accomplish in initial interactions, we need to not only carefully examine the interactional positioning and sequential development of criticisms in initial interactions, but the underlying cultural premises that participants bring to bear in interpreting them.

As we noted in the introduction, cross-cultural studies can consider interactions from the perspective of participants or as cultural systems. In the former case, we can formally distinguish between the understandings of cultural members (emic) and cultural nonmembers (etic). In the latter case, we can formally distinguish between culture-internal (emic) or culture-comparative (emic) orientation. However, maintaining such distinctions in theory is one thing; operationalising them in practice is another. In this section, we propose that it becomes easier to disentangle these inevitably intertwined perspectives if we maintain an analytical distinction between the sequential and indexical properties of social action. This proposal builds on earlier work by Sanders and Fitch (2001), in which they proposed two ways in which actions acquire social meaning: through their interactional positioning and through shared cultural premises.

Meaning arises, on the one hand, through the interactional positioning of turns of talk (Sanders \& Fitch 2001; see also Sacks, Schegloff \& Jefferson 1974; Schegloff 2007). Whether something counts as a criticism, for instance, depends, as we have seen, both on what has preceded the turn in question and what follows it. Indeed, as Brown and Levinson (1987) pointed out, criticisms may be implicated through a series of acts rather than being attributable to any single utterance: "a higher-level intention to issue a criticism can be conveyed by a series of acts (and responses) that are not themselves FTAs [face threatening acts], or are not the particular FTA in question" (p. 233). It is clear, then, that social actions, including criticisms, have particular sequential properties through which they are made recognisable to participants.

On the other hand, meaning also arises through the shared cultural premises "about rights and obligations, and ascribed meanings and motives, of interacting persons of particular kinds in particular situations" (Sanders \& Fitch 2001: 265; see also Garfinkel 1967). In other words, particular social actions are indexical of particular culturally relevant meanings for members. Brown and Levinson (1987) attempted to capture this idea in their claim that the extent to which criticisms are considered a face-threatening act varies across cultures (what is designated by $\mathrm{R}$ in their formula for estimating the degree of face threat of a particular speech act). For instance, they claim that "criticisms may be very big FTAs in 'shame' cultures", but may be lessened in middleclass European arguments (Brown \& Levinson 1987: 247).

To illustrate what we mean by sequential and indexical analysis, we will now move to consider the broader sequential environment of the barb we examined in excerpt (2) ("you must be fun at parties"), and how through what precedes and follows it, the participants shape the sequential and indexical meaning of that turn. We previously noted that through this ostensibly positive assessment, Natalie was in fact implying criticism of Gary for having no questions to ask her. Our claim is that this criticism is readily inferable because of what has been said prior to this particular turn.

While space precludes us from undertaking a detailed analysis of the excerpt below, we would like to draw attention to the way in which excerpt (9) begins with Gary once again bringing up the question of what they are supposed to be talking about (cf. excerpt 7). 
(9) AGA09: 7:18

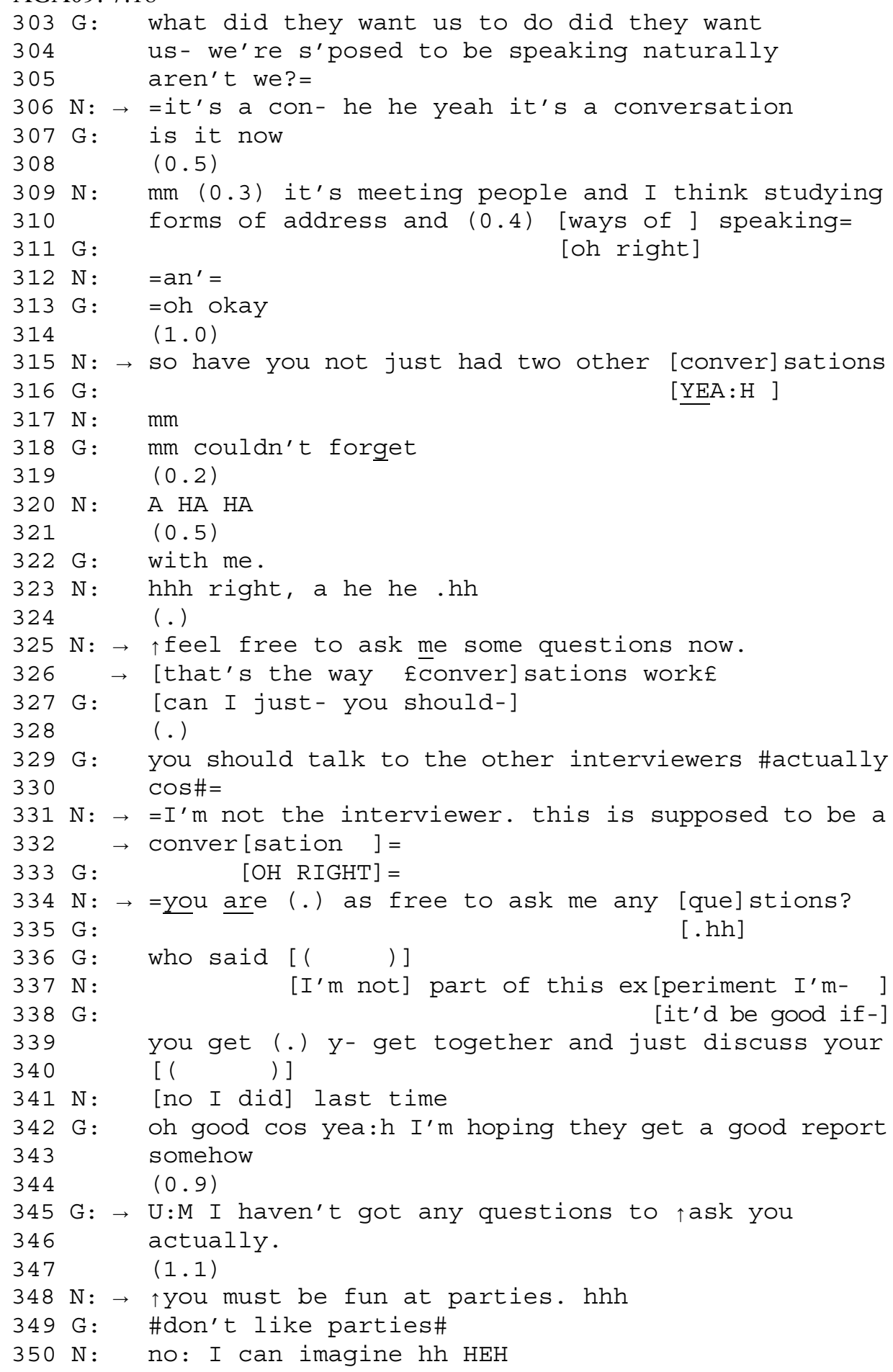

Natalie responds by first offering her understanding, before going on to implicate a series of increasingly pointed criticisms of Gary's lack of understanding about "the way conversations work" (lines 306, 315, 326, 331-332), and her expectation that he 
reciprocate the questions she has asked him by "asking her questions" (lines 325,334 ). Gary's response that he does not have any questions to ask her (lines 329-330) takes on new meaning in light of repeated exhortations by Natalie that he engage in proper (read "polite") conversation by asking her questions. It is also clear that what is implied by Natalie's sarcastic positive assessment in line 348 is not simply that Gary would not be fun at parties, but that this is because he is a poor conversationalist. It also serves as a reproach of his response to her prior request that he has no questions to ask her .

What follows this barb also subsequently shapes the meaning it takes on, as we can see in excerpt (10), which follows on from excerpt (9). Immediately following Gary's claim to not like parties is an upgraded barb in which Natalie suggests "parties", which metonymically stands for "people" here, "probably don’t like you either" (line 351).

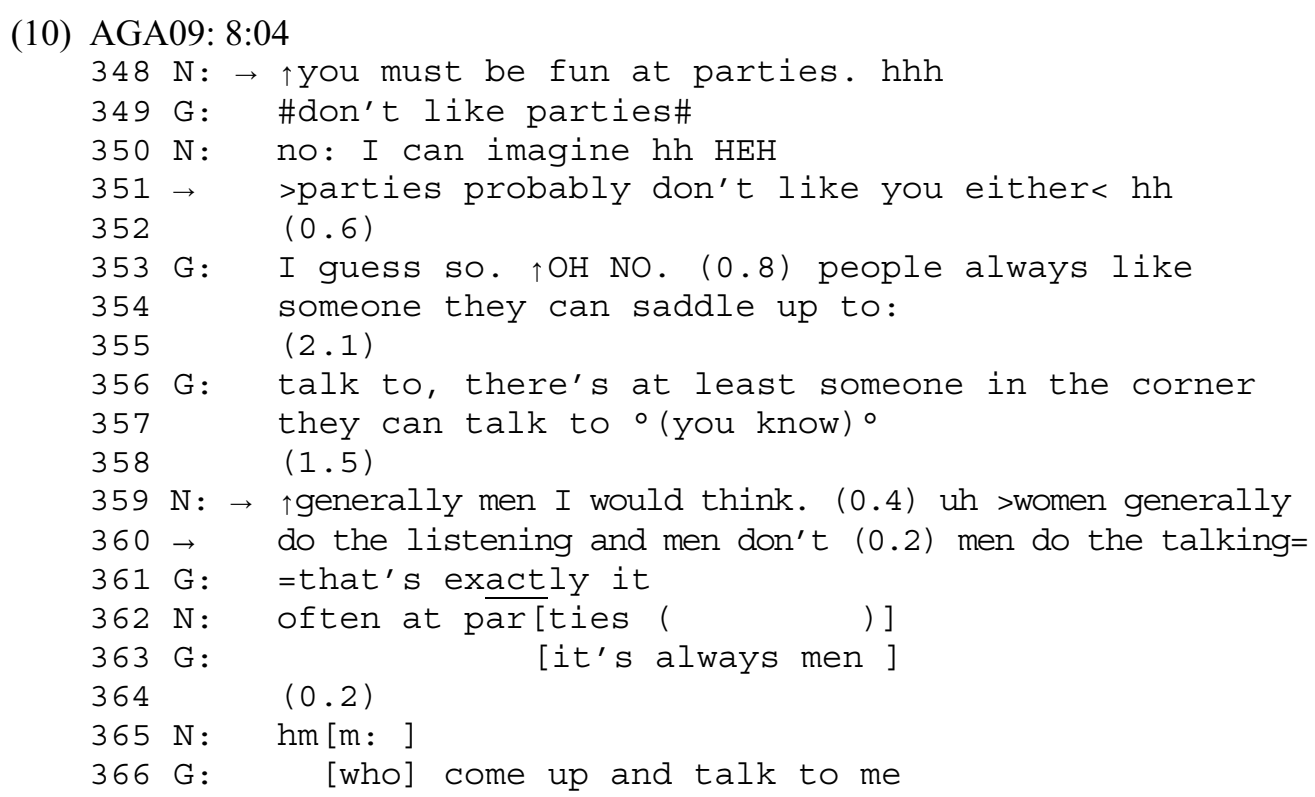

While Gary initially agrees with Natalie's explicitly negative assessment, he then backtracks with an account that there are always some people at parties who like "someone they can saddle up to" or "someone in the corner" they can talk to (lines 353357). Natalie indicates she understands this to mean Gary is claiming to be someone who is quiet, and thus a good listener, by making a more general complaint about it normally being women who do the listening, while men do the talking (lines 359-360). Gary emphatically agrees with this complaint (line 361 ), and then proceeds to upgrade it in line 363 through an extreme case formulation (Pomerantz 1986). What started out as a criticism of Gary's conduct in the interaction, and of his character, has morphed into a complaint about men in general, a complaint with which Gary himself appears to strongly agree.

A sequential analysis of criticisms does not, however, on its own warrant claims about "impoliteness". In order to analyse the potential "impoliteness" value of these criticisms we need to consider the indexical value of these criticisms from an emic per-

${ }^{7}$ See Haugh (2015b: 160-164) for discussion. 
spective. In other words, we need to tease out the cultural premise these participants are likely to bring to bear in interpreting their indexical value. One key observation we can make is that the target of judgment has shifted from criticising a co-present interlocutor to complaining about non-co-present third parties. In this way, the two interlocutors are evidently taking the heat out of a sequence in which both parties are open to evaluation as "impolite" by the other. An evaluation of Natalie as "impolite" by Gary is licensed by the way in which criticisms indicate, according to Brown and Levinson (1987), that the speaker “doesn't like/want one or more of H[earer]'s wants, acts, personal characteristics, goods, beliefs or values", and so indicates s/he "does not care about the addressee's feelings, wants, etc.” (p. 66). In other words, Gary could legitimately claim Natalie is being "impolite" ("rude", "discourteous" etc.), given the general "constraint against criticism of others", a constraint which was noted in passing by Brown and Levinson (1987: 37), and formulated more formally as a preference principle by PilletShore (2015, 2016; see also Pomerantz 1984: 78). It is worth noting, however, that this potentially "impolite" criticism is occasioned by conduct - not returning questions in a setting in which one expects them to be reciprocated (Haugh \& Carbaugh 2015) which Natalie is construing as "impolite" through this series of barbs directed at Gary. In other words, Natalie's "impolite” barbs may well be licensed by Gary's "impolite" refusal to reciprocate by asking her questions.

The key point to note here is that the indexical value which can be legitimately attached to these barbs is shaped by a set of cultural premises that are presumed to be shared amongst Australian speakers of English. These include normative assumptions about how we should conduct ourselves in initial interactions (e.g. we are expected to reciprocate questions about the other) (e.g. Haugh \& Carbaugh 2015; Svennevig 2014), as well as normative constraints on the extent to which we are licensed to criticise (or more broadly judge) others in different settings (Brown \& Levinson 1987; PilletShore 2015, 2016; Pomerantz 1984). These cultural premises underpin the oft made claim that other-criticisms threaten the "positive" face of recipients. We would suggest that criticisms also amount to a claim of moral authority, that is, an entitlement to judge others, by the speaker. For those reasons, criticisms are not only treated as dispreferred, but as acts that are clearly open to evaluation as "impolite" in initial interactions.

The question from a comparative perspective, then, is whether the same cultural premises about criticisms that we can see at work amongst Australian speakers of English in initial interactions also hold in the case of Taiwanese speakers of Mandarin Chinese. Our view is that they do not. We claim that while from a sequential perspective criticisms do indeed work in similar ways across the two languages, the cultural premises attached to those criticisms are different from an indexical perspective, and so the culturally relevant meanings made available by them also differ.

In the following excerpt taken from MCDC, for instance, Chang has been talking about the various after-school activities his sons are involved in ${ }^{8}$.

${ }^{8}$ We have used italics in the translated version to indicate utterance-final particles in this excerpt that are difficult to translate directly into English (specifically, $l a, y e, a$, and $o$ ). 
(11) MCDC09:07\&07: 2:42:

242 張: 他現在上課就是游泳啦 : :

243 王: hhe-[hehh]

244 張：[畫畫 ] 啦：：(.) 然後那個什麼-

245 王： $\rightarrow$ 當你的兒子也很累耶 (.) [我覺得啦]

246 張： [所以我就] 覺得

247 他們很累啊=

248 王：=黑啊 (.) 其實很多其實都是父母給他的，

249 因為你們就 - 就會有那種觀念啊

$250 \quad$ (.)

251 王：[不過也是，栽培啦，也是栽培啦：]

252 張: [不過有些東- 有些東西我是- 我是會比較]

253 像游泳，他們這一次他們，他們就拒絕，

254 學: 游泳=

255 王：＝哦他們沒興趣 [喔: ]

256 張: [但是] 我- 我要- 我跟他們講,

257 我可以同意他們不學游泳，

258 但是一個條件 $=$

259 王: =恩=

260 張：=就是一定要 (.) 能夠游一百公尺以上

261 [我]才能夠同意=

262 王: [哦]

263 王: =哼

$242 \mathrm{C}$ : the lessons he takes now are swimming

$243 \mathrm{~W}:$ hhe- [he heh ]

$244 \mathrm{C}: \quad$ [painting] la: : and then-

$245 \mathrm{~W}: \rightarrow$ being your sons is also tiring ye (.) [I think la]

246 C: they are tired $a=$

$248 \mathrm{~W}$ : =right (.) actually, a lot are given by parents,

249 because you- there is that kind of mindset

$250 \quad$ (.)

251 [but it's also, preparing for, also preparing for ya:]

$252 \mathrm{C}$ : [but there are some thing- some things I- that I will

253 be more] like swimming, this time they are,

254 they refused to le:arn swimming=

$255 \mathrm{~W}$ : oh they are not interested [0: ]

$256 \mathrm{C}:$ [but] I- I need- I told them,

257 I can agree that they don't learn swimming,

258 but there is one condition=

$259 \mathrm{~W}: \quad=\mathrm{mm}=$

$260 \mathrm{C}$ : =they must be (.) able to swim more than one hundred

261

$262 \mathrm{~W}:$

$263 \mathrm{~W}:=$ hmm right

The excerpt begins at the point Chang starts listing these after school activities, which include swimming and painting (lines 242-244). The barb in question arises 
in line 245 when Wang suggests that it must be tiring to be Chang's sons, followed by a turn-final epistemic marker $(l a)$ that indexes a claim to epistemic authority by Wang (Endo 2013). The inference made available through that assessment is that Chang is an overly pushy parent. Chang responds, however, by redoing Wang's assessment as an upshot (lines 246-247), thereby resisting Wang's claim to epistemic authority by claiming first-hand knowledge of his own sons, and marking his son's tiredness as already known to his though a turn-final $a$ particle (Wu 2004: 224). The negative evaluative import of Wang's initial assessment in line 245 becomes apparent in Wang's subsequent account in lines 248 - 251, in which she references a more general discourse about parents who see the need to prepare their children to compete in society through learning lots of different things, and Chang's account, in lines 252-261, in which he paints himself as a father who insists on his children learning things for their own good (in this case being able to swim a minimum distance).

However, while both participants appear to orient to Wang's initial assessment as implying a criticism of Chang's parenting style, what this criticism indexes here from an emic perspective is different to how it might be interpreted in Brown and Levinson's account, in which it would be treated as a threat to the recipient's positive face. Instead, we argue that what is indexed through Wang's implied criticism is a claim to knowledge about Chang. In presuming this knowledge about the other, Wang indexes familiarity with Chang, thereby projecting relational connection, as well as claiming epistemic authority (Chang forthcoming). With respect to the latter, by offering an assessment of how Chang's sons must feel, Wang is presuming knowledge not only about the state of Chang's sons, but also about Chang's parenting style. Previous research has indicated that displays of knowledge in a Chinese cultural context allow the speaker to "gain face" (Ho 1976; Kinnison 2017). The "face" that is gained is not positive or negative face in the sense outlined by Brown and Levinson (1987), however, but rather the emic notion of "mask/image face", that is, "one's façade to impress others" (Kinnison 2017: 32). In others words, through criticising I claim that I know something about you, and in the Chinese cultural context, showing you know things allows one to lay claim to "face" (mianzi). It follows, then, by implying criticism of Chang, Wang is not so much claiming moral authority to judge Chang, thereby threatening Chang's "positive" face, so much as she is laying claim to epistemic authority, and thereby making a claim to "face" (mianzi) on her own part, as well as indexing familiarity with Chang.

In sum, while criticisms clearly impact on face in interactions amongst both Australians and Taiwanese, the different cultural premises underpinning the indexical value of those criticisms means we are not just dealing with different cultural instantiations of face, but very different indexical values. In the case of criticisms amongst Australian speakers of English they index threats to the positive face of the recipient, and claims of moral authority by the speaker. In the case of Taiwanese speakers of Mandarin, in contrast, criticisms index displays of familiarity or relational connection with the recipient, and claims to epistemic authority and "mask/image face" by the speaker. 


\section{Implications for studying (im)politeness across cultures}

In this case study, we have seen that barbs are treated as dispreferred in initial interactions, and that they recurrently occasion accounts (indeed, in every case we have examined). However, we have also seen that although criticisms arise and are responded to in similar ways in interactions amongst Australian speakers of English and Taiwanese speakers of Chinese, the evaluative and relational import of these criticisms is not the same across these two languages. In other words, while from an etic perspective they look similar, from an emic perspective the indexical value of those criticisms, and the relational work accomplished through them differs.

Haugh and colleagues have argued in ongoing work that a distinction can, and should, be maintained between emic understandings and participant understandings in analysing (im)politeness and related phenomena (Haugh 2009: 5; Haugh 2011: 262; Haugh 2012: 122 - 127; Haugh 2018: 161-162; Haugh \& Chang 2015: 396-397; Kádár \& Haugh 2013: 86-96). They propose that an emic understanding is properly grounded in the perspective of a cultural insider or member (in the ethnomethodological sense), and can be contrasted with the etic perspective of cultural outsiders or nonmembers, while a participant understanding is properly grounded in the footings of users in their instantiation of turns at talk (and in responses to prior talk and conduct), and can be contrasted with the perspective of observers of interaction. In formal terms, we can summarise the underlying set of distinctions as in Figure 2.

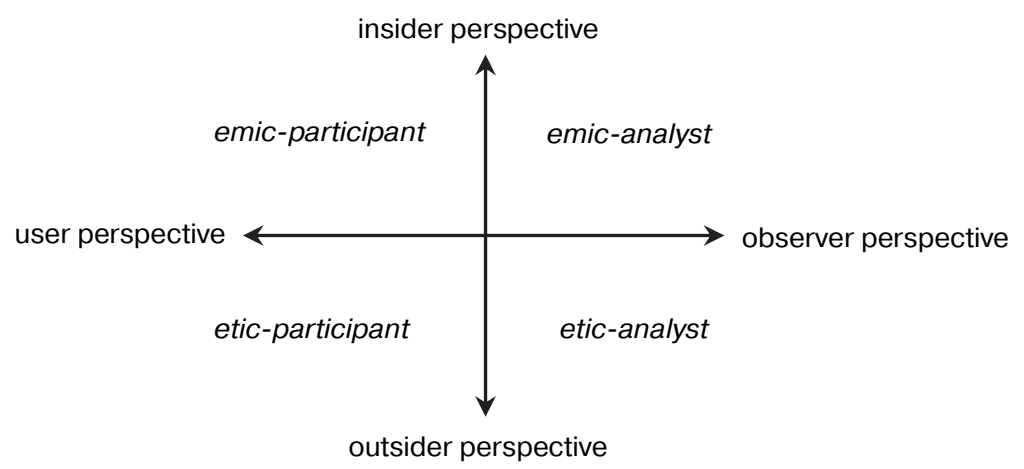

Figure 2. Emic-etic versus participant-analyst perspectives on talk and conduct

The analysis of criticisms in initial interactions in this paper indicates that this set of distinctions is one that is well worth maintaining: without taking into account the emic perspective of cultural insiders or members, we run the danger of missing important cross-cultural differences in the evaluative import of speech acts (i.e. their indexical properties), despite being interactionally accomplished in similar ways across different languages (i.e., their sequential properties). Our claim is that while criticisms are delivered through similar formats and responded to in similar ways through accounts by both Australians and Taiwanese, and thus have similar sequential properties, their evaluative and relational import are different, and so they have different indexical properties. 
In the former case they are treated as threats to positive face (of the recipient), and index moral authority (on the part of the speaker), while in the latter they are interpretable as displays of familiarity (with the recipient), and index epistemic authority (on the part of the speaker).

Our aim here has been to illustrate an emic-participant perspective on these criticisms through our respective emic-analyst lenses ${ }^{9}$. A significant challenge facing analysts, however, is that in practice participants are typically treated as members (of a particular cultural network), and so these two perspectives are, for all intents and purposes, very often laminated or fused together. Our proposal here has been that one way of operationalising the distinction between participant understandings and emic understandings is for analysts to focus on the sequential and indexical properties of social action, respectively. To analyse the sequential properties of social action one needs to build collections and identify recurrent patterns or procedures by which those social actions are interactionally accomplished. To analyse the indexical properties of social action one must identify links between locally situated meanings and the broader cultural premises which they invoke. Conversation analytic studies clearly prioritise the former, while discourse analytic studies tend to prioritise the latter. We argue that both perspectives need to be carefully integrated in order to undertake comparative analyses of speech acts across cultures. However, this raises some methodological challenges for (im)politeness researchers. For instance, how can we study the indexical properties of social action in systematic ways? Our view is that claims about these sorts of cultural premises need to be licensed themselves through much more in-depth ethnographic work about particular social actions across different interactional settings (Haugh 2007).

(Im)politeness researchers have tended to focus on differences in the linguistic forms or sequential structures by which different social actions are accomplished. Our aim here has been to draw attention to the fact that while there may be similarities in forms and sequential structure across languages, these can mask important cultural differences that are not readily apparent unless one undertakes an emic analysis of the indexical properties of social actions. While indexical analyses must be grounded in close sequential analyses of the social action in question, they also require recourse to an understanding of the cultural premises available to those participants. Cross-cultural studies of (im)politeness should, in our view, not only focus on differences in the forms or strategies by which speech acts are accomplished, but remain alert to the possibility that what is ostensibly the same speech act, may in fact be interpreted in different ways by members of different cultural groups.

(C) Michael Haugh and Wei-Lin Melody Chang, 2019 cc) creative

https://creativecommons.org/licenses/by/4.0/

9 A notable, perhaps contentious, assumption we are making is that Brown and Levinson's notions of positive and negative face are not legitimate etic categories for analysing "face" across languages and cultures, but rather represent emic categorisations relevant to Anglo-English speakers (Haugh 2006). 


\section{ACKNOWLEDGMENTS}

The research reported here was undertaken with support from a grant by the Chiang Ching-kuo Foundation (RG029-P-25). We would like to thank the two anonymous reviewers for their very helpful feedback and thought-provoking comments on an earlier version of this paper.

\section{REFERENCES}

Asmuß, Birte (2008). Performance appraisal interviews. Preference organisation in assessment sequences. Journal of Business Communication, 45(4), 408-429.

Bolden, Galina \& Jeffrey Robinson (2011). Soliciting accounts with why-interrogatives in conversation. Journal of Communication, 61 (1), 94-119.

Bousfield, Derek (2008). Impoliteness in Interaction. Amsterdam: John Benjamins.

Brown, Penelope, \& Stephen Levinson (1978). Universals in language usage: politeness phenomena. In E. Goody (ed.), Questions and Politeness (pp. 56-311). Cambridge: Cambridge University Press.

Brown, Penelope, \& Stephen Levinson (1987). Politeness. Some Universals in Language Usage. Cambridge: Cambridge University Press.

Carbaugh, Donal (2005). Cultures in Conversation. London: Routledge.

Chang, Wei-Lin Melody (forthcoming). "It's tiring to be your son": Criticisms in Taiwanese Chinese initial interactions. Journal of Pragmatics.

Copland, F. (2011). Negotiating face in feedback conferences: a linguistic ethnographic analysis. Journal of Pragmatics, 43 (5), 3832-3843.

Couper-Kuhlen, Elizabeth \& Margaret Selting (2018). Interactional Linguistics. Cambridge: Cambridge University Press.

Culpeper, Jonathan (2011). Impoliteness: Using Language to Cause Offence. Cambridge: Cambridge University Press.

Culpeper, Jonathan (2015). Impoliteness strategies. In A. Capone \& J. Mey (eds.), Interdisciplinary Studies in Pragmatics, Culture and Society (pp. 421-445). New York: Springer.

D'Amico-Reisner, Lynne (1983). An analysis of the surface structure of disapproval exchanges. In N. Wolfson \& E. Judd (eds.), Sociolinguistics and Language Acquisition (pp. 103-115). Rowley, MA: Newbury House.

Dayter, Daria \& Sofia Rüdiger (2018). In other words: 'The language of attraction' used by pick-up artists. English Today, 35 (2), 13-19.

Edwards, Derek \& Jonathan Potter (2017). Some uses of subject-side assessments. Discourse Studies, $19(5), 497-514$.

Eelen, Gino (2001). A Critique of Politeness Theories. Manchester: St. Jerome.

Endo, Tomoko (2013). Epistemic stance in Mandarin conversation: The positions and functions of wo juede (I feel/think). In Y. Pan \& D. Kádár (ed.), Chinese Discourse and Interaction: Theory and Practice (pp. 12-34). London: Equinox.

Flint, Natalie, Michael Haugh \& Andrew John Merrison (2019). Modulating troubles affiliating in initial interactions. The role of remedial accounts. Pragmatics, 29 (3), 384-409.

Garfinkel, Harold (1967). Studies in Ethnomethodology. Englewood Cliffs, NJ: Prentice-Hall.

Goodwin, Charles \& Marjorie Harness Goodwin (1992). Assessments and the construction of context. In A. Duranti \& C. Goodwin (eds.), Rethinking Context: Language as an Interactive Phenomenon (pp. 151-189). Cambridge: Cambridge University Press.

Grainger, Karen (2013). Of babies and bath water: Is there any place for Austin and Grice in interpersonal pragmatics? Journal of Pragmatics, 58, 27-38. 
Hambling-Jones, Oliver \& Andrew John Merrison (2012). Inequity in the pursuit of intimacy: An analysis of British pick-up artist interactions. Journal of Pragmatics, 44, 1115-1127.

Haugh, Michael (2006). Emic perspectives on the positive-negative politeness distinction. Culture, Language and Representation, 3, 17-26.

Haugh, Michael (2007). The discursive challenge to politeness theory: an interactional alternative. Journal of Politeness Research, 3 (2), 295-317.

Haugh, Michael (2009). Face and interaction. In F. Bargiela-Chiappini \& M. Haugh (Eds.), Face, Communication and Social Interaction (pp. 1-30). London: Equinox.

Haugh, Michael (2011). Humour, face and im/politeness in getting acquainted. In B. Davies, M. Haugh, \& A. Merrison (eds.). Situated Politeness (pp. 165-184). London: Continuum.

Haugh, Michael (2012). Epilogue: The first-second order distinction in face and politeness research. Journal of Politeness Research, 8 (1), 111-134.

Haugh, Michael (2015a). Impoliteness and taking offence in initial interactions. Journal of Pragmatics, $86,36-42$.

Haugh, Michael (2015b). Im/politeness Implicatures. Berlin: Mouton de Gruyter.

Haugh, Michael (2018). Theorising (im)politeness. Journal of Politeness Research, 14 (1), 153-165.

Haugh, Michael \& Donal Carbaugh (2015). Self-disclosure in initial interactions amongst speakers of American and Australian English. Multilingua, 34 (4), $461-493$.

Haugh, Michael \& Chang, Wei-Lin Melody. (2015). Understanding im/politeness across cultures: an interactional approach to raising sociopragmatic awareness. IRAL: International Review of Applied Linguistics, 53 (4), 389-414.

Haugh, Michael \& Simon Musgrave (2019). Conversational lapses and laughter: Towards a combinatorial approach to building collections in conversation analysis. Journal of Pragmatics, 143, 279-291.

Haugh, Michael \& Danielle Pillet-Shore (2018). Getting to know you: Teasing as an invitation to intimacy. Discourse Studies, 20 (2), 246-269.

Headland, Thomas, Kenneth Pike \& Marvin Harris (eds.) (1990). Emics and Etics. The Insider/ Outsider Debate. Newbury Park: Sage.

Heritage, John (1988). Explanations as accounts: a conversation analytic perspective. In C. Antaki (ed.). Analysing Everyday Explanation: A Casebook of Methods (pp. 127-144). London: Sage.

Ho, David Yau-fai (1976). On the concept of face. American Journal of Sociology, 81 (4), 867-884.

House, Juliane \& Gabriele Kasper (1981). Politeness makers in English and German. In Florian Coulmas (ed.). Conversational Routines (pp. 157-185). The Hague: de Gruyter.

Jefferson, Gail (2004). Glossary of transcript symbols with an introduction. In Gene Lerner (ed.). Conversation Analysis: Studies from the First Generation (pp. 13-23). Amsterdam: John Benjamins.

Kádár, Dániel Z. \& Michael Haugh (2013). Understanding Politeness. Cambridge: Cambridge University Press.

Kinnison, Li Qing (2017). Power, integrity and mask — an attempt to disentangle the Chinese face concept. Journal of Pragmatics, 114, 32-48.

Lang, Jun (2018). 'I am not criticizing you'. A constructionist analysis of an indirect speech act. Chinese Language and Discourse, 9 (2), 184-208.

Leech, Geoffrey (1983). Principles of Pragmatics. London: Longman.

Li, Sarah, \& Clive Seale (2007). Managing criticism in PhD supervision: A qualitative case study. Studies in Higher Education, 32 (4), 511-526. 
Malle, Bertram, Steve Guglielmo \& Andrew Monroe (2014). A theory of blame. Psychological Inquiry, $25(1), 147-186$.

Mills, Sara. (2003). Gender and Politeness. Cambridge: Cambridge University Press.

Morris, G.H. (1988). Finding fault. Journal of Language and Social Psychology, 7 (1), 1-25.

Nguyen, Thi Thuy Minh (2008). Criticising in an L2: pragmatic strategies used by Vietnamese EFL learners. Intercultural Pragmatics, 5 (1), 41-66.

Pillet-Shore, Danielle (2015). Being a "good parent" in parent-teacher conferences. Journal of Communication, 65 (2), 373-395.

Pillet-Shore, Danielle (2016). Criticizing another's child: How teachers evaluate students during parent-teacher conferences. Language in Society, 45 (1), 33-58.

Pomerantz, Anita (1984). Agreeing and disagreeing with assessments: some features of preferred/ dispreferred turn shapes. In J. Maxwell Atkinson \& John Heritage (eds.), Structures of Social Action : Studies in Conversation Analysis (pp. 57-101). Cambridge: Cambridge University Press.

Pomerantz, Anita (1986). Extreme case formulations: a way of legitimizing claims. Human Studies, 9, 219-229.

Robinson, Jeffrey \& GalinaB olden (2010). Preference organization of sequence-initiating actions: the case of explicit account solicitations. Discourse Studies, 12 (4), 501-533.

Sacks, Harvey, Emanuel Schegloff \& Gail Jefferson (1974). A simplest systematics for the organisation of turn-taking for conversation. Language, 50, 696-735.

Sanders, Robert \& Kristine Fitch (2001). The actual practice of compliance seeking. Communication Theory, 11 (3), 263-289.

Schegloff, Emanuel (2007). Sequence Organization in Interaction. Cambridge: Cambridge University Press.

Schuer, Jann (2014). Managing employees' talk about problems in work in performance appraisal interviews. Discourse Studies, 16 (3), 407-429.

Shaw, Chloe, Alexa Hepburn \& Jonathan Potter (2013). Having the last laugh: on post-completion laughter particles. In Phillip Glenn \& Elizabeth Holt (eds.), Studies of Laughter in Interaction (pp. 91-106). London: Bloomsbury.

Sifianou, Maria \& Pilar Garcés-Conejos Blitvich (2017). (Im)politeness and cultural variation. In Jonathan Culpeper, Michael Haugh, \& Dániel Z. Kádár (eds.). The Palgrave Handbook of Linguistic (Im)politeness (pp. 571-599). London: Palgrave Macmillan.

Spencer-Oatey, Helen \& Dániel Z. Kádár (2016). The bases of (im)politeness evaluations: culture, the moral order and the East-West debate. East Asian Pragmatics, 1 (1), 73-106.

Stivers, Tanya (2008). Stance, alignment, and affiliation during storytelling: when nodding is a token of affiliation. Research on Language and Social Interaction, 41 (1), 31-57.

Stivers, Tanya \& Fredrico Rossano (2010). Mobilising response. Research on Language and Social Interaction, 43 (1), 3-31.

Svennevig, Jan (1999). Getting Acquainted in Conversation. Amsterdam: John Benjamins.

Svennevig, Jan (2014). Direct and indirect self-presentation in first conversations. Journal of Language and Social Psychology, 33 (3), 302-327.

Tayebi, Tamineh (2018). Implying an impolite belief: a case of tikkeh in Persian. Intercultural Pragmatics, 15 (1), 89-113.

Tracy, Karen \& Eric Eisenberg (1990/91). Giving criticism: a multiple goals case study. Research on Language and Social Interaction, 24 (1), 37-70. 
Tracy, Karen, Donna Van Dusen \& Susan Robinson (1987). 'Good' and 'bad' criticism: A descriptive analysis. Journal of Communication, 37 (1), 46-59.

Tseng, Shu-Chuan (2004). Processing spoken Mandarin corpora. Traitement Automatique des Langues. Special Issue: Spoken Corpus Processing, 45 (2), 89-108.

Tseng, Shu-Chuan (2008). Spoken corpora and analysis of natural speech. Taiwan Journal of Linguistics, 6 (2), 1-26.

Vanderveken, Daniel (1990). Meaning and Speech Acts. Cambridge: Cambridge University Press.

Watts, Richard, Sachiko Ide \& Konrad. Ehlich (1992). Introduction. In Richard Watts, Sachiko Ide, \& Konrad Ehlich (eds.). Politeness in Language. Studies in its History, Theory and Practice (pp. 1-17). Berlin: Mouton de Gruyter.

Wierzbicka, Anna (1987). English Speech Act Verbs. A Semantic Dictionary. Sydney: Academic Press.

Wilkinson, Sue \& Celia Kitzinger (2006). Surprise as an interactional achivement: reaction tokens in conversation. Social Psychology Quarterly, 69 (2), 150-182.

Wu, Ruey-Jiuan (2004). Stance-in-Talk: A Conversation Analysis of Mandarin Final Particles. Amersterdam: John Benjamins

\section{Article history:}

Received: 30 September 2019

Revised: 05 October 2019

Accepted: 25 October 2019

\section{История статьи:}

Дата поступления в редакцию: 30 сентября 2019

Дата принятия к печати: 25 октября 2019

\section{Bionotes:}

MICHAEL HAUGH is Professor of Linguistics in the School of Languages and Cultures at the University of Queensland. His research interests include pragmatics, conversation analysis, intercultural communication and humour studies, with a particular focus on the role of language in social interaction.

Contact information: michael.haugh@uq.edu.au

WEI-LIN MELODY CHANG is Lecturer in Chinese in the School of Languages and Cultures at the University of Queensland. Her research interests include (im)politeness and face, intercultural communication and business discourse, and teaching Chinese as second language.

Contact information: melody.chang@uq.edu.au

\section{Сведения об авторах:}

МАЙКЛ ХО - профессор лингвистики, преподает в Школе языков и культур Университета Квинсленда, Австралия. Его исследовательские интересы включают прагматику, конверсационный анализ, межкультурную коммуникацию и изучение юмора, особое внимание он уделяет изучению роли языка в социальном взаимодействии.

Контактная информация: michael.haugh@uq.edu.au

ВЕЙ-ЛИН МЕЛОДИ ЧАНГ преподает китайский язык в Школе языков и культур Университета Квинсленда. Ее исследовательские интересы включают (не)вежливость, межкультурную коммуникацию, деловой дискурс, а также преподавание китайского языка как иностранного.

Контактная информация: melody.chang@uq.edu.au 